\title{
A TEOCRATIZAÇÃO, PRIVATIZAÇÃO E MILITARIZAÇÃO NO GOVERNO BOLSONARO: PERSPECTIVAS ANTI DEMOCRÁTICAS E CONTRÁRIAS À EDUCAÇÃO
}

\author{
Clarissa De Franco* \\ Eduardo Meinberg de Albuquerque Maranhão Filho**
}

\section{RESUMO}

O artigo dá continuidade a um estudo anterior nosso (Clarissa De FRANCO; Eduardo MARANHÃO $F^{\circ}$, no prelo), no qual desenvolvemos análise discursiva das falas de três representantes do atual governo federal, buscando identificar como as perspectivas de privatização e teocratização do mesmo têm alicerçado e oprimido a educação - especialmente as políticas educacionais em direitos humanos. Ampliamos esta discussão no presente texto, trazendo uma terceira categoria de análise: a militarização. Identificamos, em discursos governamentais, alguns mecanismos que opõem as categorias aqui levantadas (privatização, teocratização e militarização) a valores plurais religiosos, de gênero e ideológicos. Também identificamos nas falas e ações de representantes do governo a reprodução e o reforço de um pensamento dicotômico e reducionista que estabelece fronteiras cognitivas e dificultam políticas favoráveis às diversidades. Tal pensamento relaciona-se à ideologia de gênesis (Eduardo MARANHÃO $F^{\circ}$, 2017) que permeia as bases narrativas de algum modo doutrinárias do governo, alicerçando suas ações privatistas, teocráticas e beligerantes. Palavras-chave: Governo Bolsonaro; Educação em direitos humanos; Religião; Gênero.

* Psicóloga e Professora Colaboradora do curso de Pós-Graduação em Direitos Humanos da UFABC, Doutora em Ciência da Religião com Pós-Doutorado em Estudos de Gênero. Servidora da Educação na UFABC com atuação em direitos humanos, gênero e saúde mental. Secretária-Geral da Associação Internacional de Estudos de Afetos e Religiões (AMAR).

** Presidência da Associação Internacional de Estudos de Afetos e Religiões (AMAR). Docente-visitante do Programa de Pós-Graduação em Direitos Humanos, Cidadania e Políticas Públicas (PPGDH/UFPB) e do Centro de Ciências Jurídicas da Universidade Federal da Paraíba (CCJ/UFPB); Pós-Doutorado em Ciências das Religiões pela Universidade Federal da Paraíba (UFPB, 2018); Pós-Doutorado Interdisciplinar em Ciências Humanas pela Universidade Federal de Santa Catarina (UFSC) e Pós-Doutorado em História pela Universidade Federal de Santa Catarina (UFSC); Doutorado em História Social pela Universidade de São Paulo (USP); Mestrado em História do Tempo Presente pela Universidade do Estado de Santa Catarina (UDESC); Coordenação da Fogo Editorial. E-mail: edumeinberg@gmail.com 

BOLSONARO GOVERNMENT: ANTI DEMOCRATIC PERSPECTIVES AGAINST EDUCATION

\section{ABSTRACT}

The article continues a previous study of ours (Clarissa De FRANCO; Eduardo MARANHÃO $\mathrm{F}^{\circ}$, in press), in which we developed discursive analysis of speeches by three government representatives, seeking to identify how the prospects for privatization and theocratization of the current federal government have grounded and oppressed education - especially educational policies on human rights. In the present text, we expand this discussion, bringing a third category of analysis: militarization. We identified, in government speeches, some mechanisms that oppose the categories raised here (privatization, theocratization and militarization) to plural religious, gender, ideological and other values. We also identified in the speeches and actions of government representatives the reproduction and reinforcement of a dichotomous and reductionist thinking that establishes cognitive boundaries that hinder policies favorable to diversity. Such thinking is related to a certain ideology of genesis (Eduardo MARANHÃO $\mathrm{F}^{\circ}$, 2017) that permeates the narrative bases (in some way doctrinal) of the government, basing its privatist, theocratic and belligerent actions.

Keywords: Bolsonaro Government; Human rights education; Religion; Gender.

\section{TEOCRATIZACIÓN, PRIVATIZACIÓN Y MILITARIZACIÓN EM EL GOBIERNO BOLSONARO: PERSPECTIVAS ANTI DEMOCRÁTICAS Y CONTRA LA EDUCACIÓN}

\section{RESUMÉN}

El artículo continúa un estudio previo nuestro (Clarissa De FRANCO; Eduardo MARANHÃO $\mathrm{F}^{\circ}$, en prensa), en el que desarrollamos un análisis discursivo de los discursos de tres representantes del gobierno, buscando identificar cómo las perspectivas de privatización y teocratización del gobierno federal actual han fundamentado y oprimido educación, especialmente las políticas educativas sobre derechos humanos. Identificamos, en discursos del gobierno, algunos mecanismos que se oponen a las categorías planteadas aquí (privatización, teocratización y militarización) a valores plurales religiosos, 
de género, ideológicos y de otro tipo. También identificamos en los discursos y acciones de los representantes del gobierno la reproducción y el refuerzo de un pensamiento dicotómico y reduccionista que establece límites cognitivos que obstaculizan las políticas favorables a la diversidad. Tal pensamiento está relacionado con una cierta ideología de génesis (Eduardo MARANHÃO Fº 2017) que impregna las bases narrativas (de alguna manera doctrinales) del gobierno, basando sus acciones privatistas, teocráticas y beligerantes.

Palabras clave: Gobierno Bolsonaro; Educación en derechos humanos; Religión; Género

\section{INTRODUÇÃO}

Conforme indicamos no resumo, este artigo traz um complemento analítico a outra produção nossa recente (Clarissa De FRANCO; Eduardo MARANHÃO $F^{\circ}$., no prelo). A proposta central desse texto é de que existe um tripé de valores - que aqui também estão sendo utilizados como categorias de análise discursiva - que afeta significativamente o contexto de educação em direitos humanos no governo Bolsonaro: privatização, teocratização e militarização. Compreendemos, conforme demonstraremos ao longo da pesquisa, que o conceito de pluralidade, seja religiosa, de gênero, ou outras, está ameaçado por estas três perspectivas no governo Bolsonaro, afetando a educação de modo potente. Este tripé discursivo, especialmente no tocante à teocratização, fundamenta-se, por sua vez, no que pode ser convencionado como ideologia de gênesis (Eduardo MARANHÃO Fº, 2017 e 2018a e b; Eduardo MARANHÃO $\mathrm{F}^{\circ}$; Clarissa De FRANCO, 2019), como veremos no texto.

O foco deste texto volta-se à interface entre educação, religião, direitos humanos e gênero, tendo como objetivo principal observar como as perspectivas de privatização, teocratização e militarização são articuladas pelo governo em confronto com a noção de pluralidade, em especial a pluralidade sexual e de gênero.

Para observar tais valores, apoiamo-nos em falas e políticas de representantes do governo e em análises sociais. No percurso do texto apresentaremos as três categorias de análise, demonstrando como elas têm permeado as principais práticas discursivas e ações do governo Bolsonaro, procurando articular com algumas das questões de gênero aí presentes (especialmente com a perspectiva de ideologia de gênesis) e 
demonstrando parte do impacto deste tripé (privatização, teocratização e militarização) na educação.

\section{PRIVATIZAÇÃO COMO VALOR MORAL EM OPOSIÇÃO À PLURALI- DADE DA ESFERA PÚBLICA}

Maria Abádia da Silva afirma que "a privatização da educação pode se expressar em duas dimensões: uma, a redução e realocação de recursos estatais para a educação básica e superior, e a outra, a destinação de recursos públicos para o setor privado" (Maria DA SILVA, 2005, p. 260).

Ao que as ações e políticas do ministério da educação indicam, ambas as dimensões estão presentes na gestão de Abraham Weintraub. Em abril de 2019, o ministro anunciou o congelamento de 1,7 bilhões do orçamento das universidades, atingindo fortemente despesas de custeio, como luz, pagamento de terceirizadxs', equipamentos de laboratório, bolsas de pesquisa, entre outros. No anúncio dos cortes o ministro indicou que as verbas seriam cortadas em algumas universidades específicas como UNB, UFBA e UFF, que fariam, segundo ele, "balbúrdia". A fala do ministro foi: "Universidades que, em vez de procurar melhorar o desempenho acadêmico, estiverem fazendo balbúrdia, terão verbas reduzidas. (...) A universidade deve estar com sobra de dinheiro para fazer bagunça e evento ridículo (...) Sem-terra dentro do campus, gente pelada dentro do campus" (Abraham WEINTRAUB, 2019C). Após esse movimento inicial o corte se estendeu a todas as universidades, ainda que algumas bolsas tenham sido restabelecidas. Em 2020, o Ofício

\footnotetext{
A utilização de "x" trata-se da designação de sexo/gênero em linguagem inclusiva.

A palavra "balbúrdia" - que foi alvo de muita repercussão nas redes sociais - foi apresentada como um recurso retórico de impacto e é colocada como oposta à ideia de "desempenho acadêmico". Nesse sentido, balbúrdia poderia representar baixo desempenho. No entanto - e aqui utilizamos dados externos ao discurso para apoiar nossa análise -, as três universidades acusadas pelo ministro na época de sua fala de realizarem "balbúrdia" (UFF, UFBA e UNB), ao contrário do critério indicado pelo ministro, subiram em rankings universitários internacionais. Mais detalhes podem ser observados na reportagem de https:/www.nsctotal.com.br/ noticias/mec-cortara-verba-de-universidades-por-balburdia-diz-ministro (acesso em fevereiro de 2020) mostra que as três universidades subiram de desempenho nos últimos anos, levando em conta rankings como o da britânica Times Higher Education. Ver também: ttps://g1.globo. com/educacao/noticia/2019/05/15/entenda-o-corte-de-verba-das-universidades-federais-e-saiba-como-sao-os-orcamentos-das-10-maiores.ghtml. Acesso em janeiro de 2020.
} 
08/2020/GAB/SPO/SPO do MEC apontou como normativa das universidades públicas não fazerem contratações, progressões, horas extras nem nenhum tipo de despesa com pessoal ativo e inativo sem previsão orçamentária, anunciando que a previsão deste ano seria de 2,7 milhões a menos que o ano anterior. Ou seja, a perspectiva privativista, de cortes na educação pública, permanece.

A fala de Weintraub sobre balbúrbia opera no contexto de condicionar, sob uma lógica da ameaça, os recursos destinados às universidades públicas, como se estes pudessem ser atrelados ao bom ou mau comportamento das instituições federais de ensino. A visão de Weintraub sugere uma perspectiva privatizada para a gestão pública do campo educacional.

Nesse âmbito, apontamos nosso primeiro argumento, já indicado em estudo anterior (Clarissa De FRANCO; Eduardo MARANHÃO F, no prelo), que propõe que o governo Bolsonaro e seus(suas) representantes assumem a privatização como um valor que se contrapõe à pluralidade de pensamentos, esta última identificada com a coisa pública. O discurso de Weintraub sugere que o alinhamento ideológico das universidades ao governo é uma condição para seu desenvolvimento, e tal condição não representa a lógica de manejo da coisa pública, sendo alinhada a uma perspectiva empresarial privada.

Observamos em artigo anterior (Clarissa De FRANCO; Eduardo MARANHÃO $F^{\circ}$, no prelo), que a perspectiva de privatização da coisa pública torna-se um mecanismo de resguardar valores e ideologias que são de adesão do governo. Este movimento acaba por oferecer uma forma de resistência ao contexto de pluralidade e diversidade presentes na arena pública dos contextos democráticos, uma vez que o governo passa a operar a máquina pública privilegiando um pequeno grupo de valores.

Além dos cortes, cabe considerar que, desde 2019, o Ministro da Educação Abraham Weintraub propôs o Programa Future-se, no qual as universidades públicas são convidadas a se abrirem à iniciativa privada. O Future-se veio como uma proposta de adesão voluntária, mantendo a aparente autonomia das universidades federais e também a aparente normalidade democrática, mas com a redução de verbas, muitas universidades se veem seduzidas pela possibilidade de terem sua gestão 
administrada por dinheiro privado. Tal política mostra-se um projeto de gradualmente fazer com que o público torne-se privado.

A nomeação de Benedito Aguiar Neto para a presidência da CAPES sugere um aceno à valorização da educação privada no país. Isto porque Benedito era Reitor da Universidade Presbiteriana Mackenzie. Claro que este não é um argumento definitivo, mas pode indicar, como sugerimos, um aceno, ou uma aproximação ideológica com o contexto privado da educação.

A privatização da educação insere-se em um contexto mais amplo de transformações ideológicas que têm ocorrido nas últimas décadas. Gostaríamos de trazer para o debate aquilo que chamamos de privatização como valor moral, que tem impactado fortemente a educação. Desde fins de 1990 e início dos anos 2000, observamos alguns movimentos, em especial na América Latina, que demonstram como a perspectiva de privatização está ganhando espaços no campo da educação, não só no campo econômico, mas também no plano moral.

O Escola Sem Partido, nascido como movimento no Brasil em 2004 e como Projeto de Lei em 2014 (Frank MEZZOMO, 2018; AÇÃO EDUCATIVA, 2016; Fernanda MOURA, 2016) e o movimento Con Mis Hijos No Te Metas que teve início no Peru em 2016 (Paulo BARRERA, 2017; Veronique LÉCAROS, 2018) e se espalhou por vários países na América Latina como Chile, Argentina, Costa Rica, Paraguai, Colômbia, Equador, Bolívia, denotam uma relação de propriedade dos pais e mães com seus/ as filhxs. A reivindicação comum entre os dois movimentos é a retirada do debate de gênero das escolas, deixando para pais e mães a tarefa da educação sexual e de gênero e afastando o Estado de tal tarefa.

As diretrizes globais de políticas de gênero passaram a ser um incômodo para setores religiosos tradicionais cristãos desde a década de 1990, quando mundialmente assumiu-se como política o combate à violência de gênero, e incluiu como grupo de atenção, além das muIheres, o grupo LGBT, apontando para a desconstrução da perspectiva de gênero como binária. Maria José Rosado-Nunes (2015) demonstrou que a repercussão de tais políticas nas Conferências da ONU de 1994 e 1995 em Beijin e Egito foram decisivas para o início das reações de lideranças religiosas contra a perspectiva de pluralidade. Esse combate à 
pluralidade, resgatando valores tradicionais e privativos como a família, passaram a afetar o campo da educação.

Notamos que o domínio do privado torna-se uma contraposição aos valores plurais presentes na esfera pública. Quando os debates de gênero apontam para a pluralidade, a estratégia é se refugiar no núcleo exclusivista e privativo da família. Uma série de antagonismos tem se firmado no debate entre ideologia gênero e de gênesis. Ideologia de gênero se refere à perspectiva plural de gênero vista por grupos tradicionais como destruidora da família e sexualidade tradicionais (Sara GARBAGNOLI; Mássimo PREARO, 2017), já ideologia de gênesis (Eduardo MARANHÃO $\mathrm{F}^{\circ}$, 2017) $)^{3}$ se refere à "perspectiva ideológico-religiosa que pressupõe que existem apenas dois sistemas sexo-gêneros (macho-homem / fêmea-mulher) legitimados por Deus e atrelados a uma única orientação sexual desejável, a hétero" (Clarissa De FRANCO; Eduardo MARANHÃO $F^{\circ}$, no prelo). A ideologia de gênesis se fundamenta na criação de Adão e Eva e acaba por naturalizar, de maneira pré-determinada, papeis sociais para o homem e a mulher, excluindo outras possibilidades de gênero.

O dispositivo cis-heteronormativo com bases religiosas (Eduardo MARANHÃO $F^{\circ}$, 2017) pode ser observado em várias falas de representantes do governo, como esta de Damares Alves, que ficou célebre: “atenção, atenção! É uma nova era no Brasil. Menino veste azul e menina, rosa"(Damares ALVES, 2019C). A metáfora binária das cores (azul/rosa) escancara uma rejeição à outra metáfora, a do arco-íris, que representa a pluralidade de gênero ligada ao grupo LGBT. Novamente a pluralidade é atacada como adversária da perspectiva da família tradicional cristã.

Outros discursos demonstram com maior veemência o vigor das fronteiras binárias de gênero, trazendo mais elementos para o debate, como a perspectiva de biologização do gênero. Abraham Weintraub

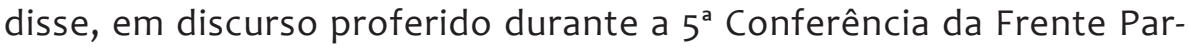
lamentar Evangélica do Congresso Nacional, realizada na Faculdade

Os conceitos de ideologia de gênesis e dispositivo da cis-heteronorma foram trabalhados anteriormente por Eduardo MARANHÃO F ${ }^{\circ}$ (2017; $2018 a$ e b). Também tratamos os conceitos em artigo anterior (Eduardo MARANHÃO $F^{\circ}$.; Clarissa De FRANCO, 2019). 
Boas Novas de Manaus, cujo tema foi "O Novo Brasil na Perspectiva Cristã", em outubro de 2019: "ou é XY no DNA e se for fêmea XX. Mas se te disserem, ah, mas eu não tenho 'pipi'. Tudo bem, você pode ser um XY macho que nasceu sem 'pipi'. Agora, se você tem atração por outro sexo, vou tratar a pessoa com todo o respeito. A Roberta Close, por exemplo, eu trataria como senhora, mas o DNA dela é de macho" (Abraham WEINTRAUB, 2019b).

Maria José Rosado-Nunes (2005) lembra que alterações no corpo, como ocorrem frequentemente com as transformações corporais vivenciadas por pessoas trans, são compreendidas no discurso da heterocisnorma como formas de desvios ou máculas do projeto divino (ROSADO-NUNES, 2005). Nesse sentido, a biologia torna-se um testemunho da "naturalidade" do corpo que Deus gerou. Judith Butler (2001), em uma importante crítica, lembra que os corpos também são construídos na cultura e que a dicotomia entre a natureza e a cultura é artificial, porque a ideia de natural é também construída.

A ministra Damares Alves também demonstrou reforço à biologização de gênero, ao dizer:

Nós temos uma diferença biológica, não importa o estado em que ela se sente, como eles falam, se se sentem mulher agora, mas biologicamente, eles são superiores às mulheres. Gente, ó, não existe essa coisa de igualdade entre o homem e a mulher quando a gente vai para o campo da Biologia. O homem é forte. Nós, mulheres, não vamos conseguir por muito tempo carregar um saco de cimento nas costas, mas eles não conseguem ver as coisas como a gente vê (Damares ALVES, 2020) $)^{4}$

Trata-se de mais um discurso de uma representante do governo que reforça a perspectiva da biologização dos corpos e consequente binarização e polarização dos sistemas sexos-gêneros. Ao trazer a ênfase

4 O contexto da frase emitida por Damares vem de uma pergunta da jogadora de vôlei e ex-atleta Ana Paula Henkel sobre a possível participação do Estado na garantia do direito das mulheres cis para não serem excluídas do esporte em função das desigualdades biológicas em relação às trans. Todo o contexto já parte de uma narrativa que tem lado: o das atletas mulheres cis, pois a pergunta veio de uma ex-atleta mulher cis. 
do debate para a biologia, os aspectos sociais de construção identitária tornam-se não só desvalorizados como aniquilados. O discurso estabelece uma comparação que revela uma forte raíz do pensamento dicotômico disseminado popularmente sobre gênero: os homens são fortes e as mulheres "veem" as coisas, envoltas em uma aura de intuição, sensibilidade e mistério que cerca o universo feminino essencialmente. A pesquisadora feminista Rae Langton (2000) aponta que as mulheres são percebidas como um "objeto misterioso", difícil de ser acessado, com uma complexidade atrelada ao universo emocional e subjetivo. $\mathrm{E}$ que tal percepção promove exclusões das mulheres de vários campos reconhecidos e valorizados socialmente, como o científico. Reforçar este pensamento é trabalhar na lógica de exclusão e apagamento da identidade das mulheres.

Além da retirada do debate de gênero, fortalecem-se no governo Bolsonaro outras iniciativas de privatização moral da educação, com destaque à proposta de educação domiciliar (ou homeschooling) proposta, por exemplo, pela atual Ministra da Mulher, Família e Direitos Humanos, a pastora "terrivelmente cristã" Damares Alves (Eduardo MARANHÃO F $F^{\circ}$, Clarissa De FRANCO, 2019). Em sua defesa sobre o tema, a ministra afirmou que "nós entendemos que é direito dos pais decidir sobre a educação dos seus filhos, é uma questão de direitos humanos. Então, a iniciativa sai deste ministério sob esta vertente. (...) E nós somos signatários do Pacto de San Jose da Costa Rica ${ }^{5}$ que garante isso às famílias" (Damares ALVES, 2019a).

Para finalizar esse item, concluímos indicando que a privatização é um dos valores que mais tem afetado (negativamente) a educação, e ao se encontrar com a teocratização e a militarização (indicadas nos próximos itens deste artigo), consolida-se uma base ideológica e de práticas que atacam de maneira frontal a educação, em especial a educação em direitos humanos, já que confrontam a pluralidade de maneira geral.

O Pacto de San Jose da Costa Rica, também conhecido como Convenção Americana de Direitos Humanos, em vigor desde 18 de julho de 1978, traz a família como o "elemento natural e fundamental da sociedade" (art.17) no artigo 12 defende o direito dos pais e mães de que seus seus/as filhxs recebam educação religiosa e moral que esteja de acordo com suas próprias conviç̧ões. É um documento que reforça a perspectiva de família tradicional e que foi aprovado na década de 1970. 


\section{A PERSPECTIVA DE TEOCRATIZAÇÃO COMO OPOSIÇÃO À PLURALIDADE LAICA}

Além da perspectiva de privatização, a teocratização pode ser observada em muitas práticas do governo Bolsonaro. Desde a campanha de 2018, várias lideranças religiosas importantes no país, como Edir Macedo, Silas Malafaia, entre outras, declaram apoio a Jair Bolsonaro. Silas Malafaia justificou que o candidato era o único que encarnava os valores que o povo brasileiro precisava "na questão dos costumes" (Tiago CHAGAS, 2018).

Com o slogan "Brasil acima de tudo, Deus acima de todos", a campanha de Bolsonaro recebeu forte apoio de Magno Malta, político e pastor evangélico. Durante o episódio da facada, Malta foi um apoiador leal, aparecendo com bençãos e orações públicas a Bolsonaro. A facada é um elemento que também pode ser compreendido como uma peça-chave dentro da ótica simbólica da teocratização. Jair, que tem Messias como nome do meio, vivenciou um fenômeno que permitiu associar sua imagem ao espaço liminar no qual se fundem sagrado e profano. Podemos evocar o clássico de Arnold Van Gennep (1909), Os Ritos de Passagem, quando trata dos ritos de margem, nos quais a liminaridade e seu aspecto instável é condição para transição. A facada foi o símbolo de várias margens: morte/vida, divino/homem comum, heroi/vilão, guerreiro/vulnerável, um candidato entre outrxs. Magno Malta pareceu decepcionado por não ter sido nomeado para algum cargo de confiança no governo Bolsonaro. Ainda assim, seu pronunciamento evocou a narrativa religiosa de que Bolsonaro havia sido eleito por Deus. "O diabo não levanta autoridade. Quem levanta autoridade é Deus. (...) O Brasil precisa de um homem patriota, que tenha Deus no coração, disposto a enfrentar a violência, proteger a escola, as crianças, e, acima de tudo, que ame Israel (Magno MALTA, 2018).

O slogan de campanha de Bolsonaro: "Brasil acima de tudo, Deus acima de todos", junto do discurso de posse no qual ele citou a palavra "Deus" seis vezes, além de ter declarado apoio nominal à tradição judaico-cristã (FOLHA DE SÃO PAULO, 2019) ${ }^{6}$, já trouxe logo de início

O trecho específico sobre a tradição judaico-cristã é: "Vamos unir o povo, valorizar a família, respeitar as religiões e nossa tradição judaico-cristã, combater a ideologia de gênero, conservando nossos valores. O Brasil voltará a ser um país livre das amarras ideológicas". 
uma posição visível que envolve mais que um aceno a uma relação, mas uma demarcação de território. Comentando sobre o assunto, Eduardo MARANHÃO $\mathrm{F}^{\circ}$., Fernanda COELHO e Tainah Biela DIAS indagavam: "Justifica-se assim a supressão de direitos de todos/as aqueles/as que não se enquadram nos padrões conservadores do credo político de Bolsonaro. Sendo assim, coloca-se "Deus" acima da democracia. Estaria Bolsonaro acima da democracia e da sociedade?" (Eduardo MARANHÃO $F^{\circ}$., Fernanda COELHO e Tainah Biela DIAS, 2018, p. 84).

Tal fixação de território que sinaliza para a quebra da laicidade também está evidenciada na fala da ministra Damares Alves que afirma, logo na posse em 02 de janeiro de 2019 (Damares ALVES, 2019b): "o Estado é laico, mas essa ministra é terrivelmente cristã". Notemos que há a delimitação de uma fronteira: laicidade $\mathrm{X}$ religião, com clara defesa da supremacia da religião sobre a laicidade, o que nos parece uma afronta a um Estado laico. A respeito da laicidade do Estado, ou separação entre Estado e religião, Flávia Biroli já notava ter sido uma

[...] solução histórica para essa diversidade, que se apresenta também como pluralidade de crenças e de credos. A laicidade é um princípio fundamental da democracia porque permite que essa diversidade se apresente sem que o Estado assuma e promova a superioridade de um grupo relativamente a outro. Quando a religião orienta políticas de Estado, rompe-se com a ideia de que os indivíduos merecem igual respeito e têm igual valor na sociedade - os valores, crenças e estilos de vida de alguns fariam deles o povo eleito, e a democracia não resiste a essa visão exclusivista e excludente (BIROLI, 2015, s/n).

Conceitualmente, os princípios da laicidade e da religião não são antagônicos. Laicidade é um conceito que envolve distintos níveis de relações entre Estado e religiões, no entanto, em Estados democráticos, envolve garantias de convivência pacífica e respeitosa entre diferentes grupos religiosos, e busca (ao menos em teoria) por não favorecimentos aos grupos religiosos majoritários, como formas de garantir uma postura o mais próxima possível da neutralidade nas relações entre Estado e religião. Fernando Catroga (2006) aponta as porosidades e diferenças em práticas de laicidade de Estados distintos. $\mathrm{O}$ autor identifica três modelos em que a laicidade se estabelece na Europa. No 
primeiro, cita países como a Inglaterra e a Dinamarca, que são sociedades com Constituição religiosa, que todavia adotam condutas práticas secularizadas. O segundo modelo, ao qual ele chama de "semi-laicidade", refere-se a Estados não confessionais, que, apesar disso, subsidiam algumas religiões, como seria o caso de países como Alemanha, Bélgica e Holanda. O último grupo que ele denomina de "quase laicidade", enquadra países ibéricos como Portugal, Itália e Espanha, os quais descreve como Estados laicos judicialmente, mas que são signatários de acordos que privilegiam grupos religiosos majoritários.

Notemos que o contexto da pluralidade não reduziu a presença das religiões no espaço público. A participação delas, inclusive, ampliou-se para a ocupação de amplos setores de abrangência pública como os veículos midiáticos desde principalmente o fim do século 20, como observa Ricardo Mariano (2011). A este respeito, Paula Montero (2009) aponta a necessidade de modificarmos nosso olhar como pesquisadorxs, superando o paradigma weberiano de secularização que pressupõe racionalização das religiões e desmagificação das sociedades, e como efeito, as religiões seriam deslocadas para a esfera privada, o que na verdade não ocorre no contexto atual.

A pluralidade religiosa é um fato que participa da composição dos Estados democráticos, fortemente perpassados na contemporaneidade por fenômenos como a globalização, a tecnologização e o intercâmbio digital, que promove fenômenos culturais híbridos (Stuart HALL, 2006). No entanto, ao reforçar uma identidade de ministra ligada a um grupo religioso majoritário, como o cristão, Damares Alves e o governo Bolsonaro assinalam, com o uso do poder do Estado, que a pluralidade religiosa estará submetida aos valores privativos de um grupo (e aqui se relacionam teocratização e privatização), ameaçando frontalmente a perspectiva de laicidade, seja qual for o modelo que se tome como referência.

Quando Damares Alves utiliza a palavra "terrivelmente" traz ênfase à sua identidade cristã. Não se trata de uma identidade cristã qualquer, mas sim de uma "terrível". E embora se refira a um campo pessoal de crenças de Damares, ao ser dita a partir do papel de ministra revela mais uma demonstração da estrita "comunhão" entre política e religião no governo Bolsonaro. Reproduzimos a fala de Jair Messias Bolsonaro no 
Twitter sobre a questão: "O Estado é laico SIM. Mas o Presidente da República é CRISTÃO, como aproximadamente $90 \%$ do povo brasileiro também o É."”. (Jair BOLSONARO, 2019).

Mesmo sendo o Brasil um país de maioria cristã, como afirmou o presidente, em um país laico, se governa para todxs, inclusive para a minoria da população. E dizer que a maior parte da população é cristã não significa dizer que estas pessoas são favoráveis a discursos como este, nem mesmo a Bolsonaro. A respeito das crenças, não há dados de que Bolsonaro e seu discurso represente (a) a maior parte de indivíduos cristãos brasileiros. E neste sentido é preciso deixar patente que há uma multiplicidade de posicionamentos ideológicos dentro do cristianismo, ou melhor, dos cristianismos contemporâneos. Se há segmentos bastante resistentes à ampliação e à horizontalizacão de direitos de todxs, ou em outras palavras, contrários à diversidade, há segmentos cristãos comprometidos com visões mais progressistas, e tal ressalva é necessária pois "em um determinado imaginário popular do tempo presente", pessoas evangélicas e católicas "são (con)fundidas com uma parcela de pessoas adeptas de tais cristianismos mas também adeptas de atitudes intolerantes e discriminatórias em relação a outras", e "certamente, nem só de conservadorismo ou/e reacionarismo vive o mundo evangélico" e católico.(Eduardo MARANHÃO F., 2015). Ressalvado isto, nos parece óbvio que Bolsonaro está longe de representar qualquer posicionamento cristão progressista, bem ao contrário, como atesta a (con)fusão que faz entre Estado laico (onde deve estar clara a separação entre política e religião) e seu atrelamento ao cristianismo (ou melhor, a uma corrente reacionária do mesmo).

Ainda sobre a flexibilização da laicidade do Estado, com claras vias de sua quebra e aniquilação, esta comunga de modo estreito com o movimento de teocratização que estamos comentando aqui. A nomeação de Benedito Aguiar Neto para a presidência da CAPES, já aqui citada, também pode ser compreendida dentro desse movimento. Presbiteriano, reitor da Universidade Mackenzie, pronunciou-se de maneira enfática, poucos meses antes de ser convidado para a cadeira, ainda como Reitor: "queremos colocar um contraponto à teoria da evolução e disseminar que a ideia da existência de um design inteligente pode 
estar presente a partir da educação básica, de uma maneira que podemos, com argumentos científicos, discutir o criacionismo" (Benedito AGUIAR NETO, 2019).

A fala de Benedito foi proferida no contexto de uma palestra do maior expoente mundial da Teoria do Design Inteligente, Michel Behe, ocorrida na Universidade Presbiteriana Mackenzie, em São Paulo, da qual é Reitor, em outubro de 2019. Benedito Aguiar Neto falou em nome do grupo de pessoas adeptas desta teoria, que é minoritário entre cientistas, e sobre a qual paira o consenso internacional (da maioria da comunidade científica) de que sua base é religiosa, fundamentada no criacionismo bíblico, que por sua vez, está ligado à ideologia de gênesis, já aqui apresentada. Isso sugere que Benedito Aguiar Neto representa uma aliança entre as perspectivas de privatização (já que era Reitor de uma universidade particular) e teocratização, uma vez que representa o discurso presbiteriano e quer disseminar o pensamento cristão na ciência. O impacto na educação aqui é evidente.

Ademais das posições de representantes aqui citados, como Damares Alves, Abraham Weintraub e Benedito Aguiar Neto, temos as próprias falas do presidente Jair Bolsonaro, que aludem à teocratização. A alusão aos textos bíblicos tornou-se frequente nos discursos de Jair Messias Bolsonaro. Em manifestação no dia 08/04/2020, usou o versículo bíblico: "E conhecereis a verdade e a verdade vos libertará" (João 8:32), colocando-se em uma posição de confirmar seu valor por meio da "verdade", em contraposição a quem se posiciona do outro lado da fronteira: xs mentirosxs.

Cabe considerar que a teocratização aliada à perspectiva de privatização fortalece a ideologia de gênesis, porque esta última tem como fundamento a crença bíblica de que Deus criou macho e fêmea, tendo o homem vindo do barro (representando estrutura material) e a mulher de sua costela, sendo compreendida biblicamente como a adjutora, ajudante e secretária do primeiro, delimitando assim, papeis e lugares sociais para o homem e para a mulher, e restringindo tais lugares a somente duas posições de gênero (Clarissa De FRANCO; Eduardo MARANHÃO Fº, no prelo; Eduardo MARANHÃO $F^{\circ}$., Clarissa De FRANCO, 2019; Eduardo MARANHÃO $F^{\circ}$., 2017). 
Conforme indicamos no item anterior, a ideologia de gênesis tem afetado o campo da educação nas últimas décadas. E aqui complementamos, indicando que a educação em direitos humanos tem sofrido ainda maior impacto com tais perspectivas, uma vez que a pluralidade tem sido vista como ameaça. O espaço da educação em direitos humanos é, por excelência, o lugar da diversidade e no qual a exposição à diversidade torna-se condição necessária da convivência e desenvolvimento das crianças e adolescentes (Maria BENEVIDES, 2007). Quando tal exposição é diminuída para priorizar o valor de um grupo ou de pequenos grupos (familiar, religioso...), a educação tona-se frágil na criação de repertórios para o mundo plural. A teocratização do governo Bolsonaro é chave desse enfraquecimento de repertórios.

\section{MILITARIZAÇÃO COMO OPOSIÇÃO AO PLURALISMO IDEOLÓGICO}

O jornal O Estado de São Paulo (2020) fez um levantamento em março de 2020 que demonstrou que há, no governo de Jair Bolsonaro, aproximadamente 130 representantes das Forças Armadas que ocupam atualmente o poder executivo federal, distribuídos no primeiro escalão (Vice-Presidente Hamilton Mourão, nove ministros, em um total de vinte e dois: Augusto Heleno, Walter Souza Braga Neto, Luiz Eduardo Ramos, Jorge Oliveira, Wagner Rosário, Fernando Azevedo e Silva, Tarcísio Gomes de Freitas, Marcos Pontes, Bento Albuquerque), segundo e terceiro escalões, como secretarias, chefias de gabinete, diretorias, presidências, como é o caso da presidência da Funai, do Incra, a Corregedoria do Ibama, participando em diferentes áreas: infraestrutura, segurança, minas e energia, ciência e tecnologia, entre outras. O número de militares no poder é maior que durante o governo do General Castelo Branco.

Os sentimentos de nacionalismo, patriotismo, aliados ao imaginário militar é algo com forte presença em diversos países da América Latina, no entanto, no governo Bolsonaro, a militarização tornou-se uma característica muito forte. O pesquisador chileno Guillermo Nugent (2005) apontou que essa junção emocional entre as forças armadas e o sentimento de patriotismo funciona como um apoio simbólico de proteção paterna social, que frequentemente gera elementos de tutelagem moral na sociedade, e consequente diminuição da autonomia dos indivíduos 
na gestão de seus valores. De acordo com pesquisa desenvolvida por Guillermo Nugent (2005), esse sentimento deu respaldo para uma tutela moral verificada na elaboração de políticas públicas na América Latina, em claro conflito com temas mais progressistas e outrora proibidos como o da sexualidade. No caso de Bolsonaro, a conceituação do autor serve-nos para identificar a força de elos emocionais e simbólicos que sustentaram sua ascensão política e mítica.

Além dos militares no poder, o governo propôs em 2019 o Programa Nacional de Escolas-Cívico Militares, que tem como meta criar, até o fim do mandato, 216 escolas. Ao lançar o Programa, o ministro da educação Abraham Weintraub afirmou: "[Que] nunca mais um regime totalitário tente ser implantado no Brasil. Nunca mais nós tenhamos uma ideologia externa tentando ser imposta aos brasileiros. Nunca mais o presidente de outro país questione a soberania deste país. Nunca mais a gente esqueça que essa bandeira jamais será vermelha" (Abraham WEINTRAUB, 2019a). A narrativa de Weintraub resgata o vigor da fronteira ideológica entre esquerda e direita e traz uma estratégia de inversão, associando regime totalitário com algo totalmente distante do modelo militar.

Além de Weintraub, Jair Bolsonaro também se pronunciou na ocasião, trazendo uma crítica comparativa sobre a democratização na educação e na polícia militar: “(...) o que aconteceu com o ensino no Brasil ao longo nas últimas décadas? Democratizou-se o ensino. (...) Queremos uma Polícia Militar eficiente e que realmente cumpra seu objetivo. Mas falar em democracia na PM? Como ele vai tratar um sequestrador, um narcotraficante?" (Abraham WEINTRAUB, 2019a).

A fala de Bolsonaro nos remete a uma ameaça ao princípio democrático. Ela sugere que o presidente acusa a democracia de ter sido responsável pela derrocada do ensino no Brasil. Além disso, contrapõe democracia e polícia, como se estivessem em instâncias diretamente opostas. A educação, diante de tais discursos, mostra-se fragilizada por uma imposição de valores de pequenos grupos não abertos à pluralidade.

Neste âmbito de militarização do governo, nunca é tarde para lembrar que o governo tem suas armas ideológicas: as notícias falsas (ou fake news), utilizadas desde a campanha de Bolsonaro à Presidência da 
República (Eduardo MARANHÃO F., Fernanda COELHO e Tainah Biela DIAS, 2018). Dentre elas, se destaca o combate à ideologia de gênero, que se ampara na ideologia de gênesis e dispositivo da cis-heteronorma que, como sinalizado acima, relacionam-se especialmente ao contexto de teocratização do atual governo.

Finalizamos esse item com a frase de Fabio Py que mostra a amálgama entre os valores de privatização, teocratização e militarização e a que situações ela tem nos conduzido:

O dado da idealização familiar, a ideia da nação e o discurso de Deus já foram utilizados como justificativas antes do Golpe Civil Militar e dentro do próprio, para, a partir de 1968, ampliar o cerceamento dos direitos civis com o Ato Institucional Número $\mathrm{n}^{\circ} 5$ (Al5). Construiu-se uma atmosfera de medo, segundo a qual o perigo é que os inimigos da família e as modernizações “manchem a nossa nação". Algo que perturba a tão importante "vida segura" tão cara à classe média brasileira. Assim, nessa primeira modulação cristofascista brasileira, a de Jair Bolsonaro, o discurso de Deus cristão (católico) se faz sob os perigos que assolam o país, impregnado de LGBTfobia e contra as minorias no geral (Fabio PY, 2018, p. 3).

\section{CONSIDERAÇÕES FINAIS}

O artigo demonstrou que o tripé privatização, teocratização e militarização permeia as práticas e os discursos do governo Bolsonaro e que tal conjunto de valores tem impactado severamente o campo da educação. Guacira Lopes Louro (2008) entende a educação como um campo de disputa discursiva no qual fronteiras de gênero têm apontado para potentes abismos cognitivos entre as partes, que impedem ou dificultam as políticas de diferença. Nesse sentido, as estratégias de privatização, teocratização e militarização têm fortalecido as fronteiras entre, de um lado, a pluralidade característica dos Estados democráticos, e de outro, valores de pequenos grupos que exaltam princípios tradicionais, como família, religião, visão binária de gênero.

Este conjunto de valores chegou à educação do Brasil há alguns anos, evidenciando-se mais fortemente na discussão do PNE (Plano Nacional de Educação) e no movimento Escola Sem Partido. No entanto, no atual governo a tensão e os prejuízos à educação em direitos 
humanos se tornaram mais evidentes e profundos, justamente porque o "lado" da trincheira que está fortalecido nesse governo é o contrário às perspectivas de pluralidade.

O pavor social criado pela ideologia de gênesis em relação à suposta "ideologia de gênero" (bem como a outras fake news divulgadas pela equipe de Bolsonaro desde sua campanha presidencial), se relaciona com o apoio pretendido da "família tradicional brasileira", que "se tornou importante capital político para políticos/as religiosos/as que se aproveitam do imaginário social para empurrar suas agendas"; sendo que o "recrudescimento de conservadorismos que vemos no Brasil, principalmente desde 2010, se consolida com a vitória de Jair Bolsonaro oferecendo novos desafios às já frágeis democracia brasileira e laicidade do Estado" (Eduardo MARANHÃO F., Fernanda COELHO e Tainah Biela DIAS, 2018, p. 85).

Destacamos por fim que, se consideradas de uma maneira isolada e dentro de limites, a privatização e militarização podem fazer parte de um Estado democrático, assim como as religiões também fazem. No entanto, quando tais valores passam a suplantar-a pluralidade, esgarça-se o princípio principal da democracia, e a isso nos declaramos diametralmente desfavoráveis.

\section{REFERÊNCIAS}

AÇÃO EDUCATIVA (Org.). A ideologia do movimento Escola Sem Partido: 20 autores desmontam o discurso. São Paulo: Ação Educativa, 2016, p. 49-58.

AGUIAR NETO, Benedito. Novo Presidente da Capes gera polêmica ao defender criacionismo. Globo, 2019. Disponível em: https://g1.globo.com/jornal-nacional/noticia/2020/01/28/novo-presidente-da-capes-gera-polemica-ao-defender-criacionismo.ghtml. Acesso em 26/01/2020.

ALVES, Damares. "Pra cima deles". Jovem Pan News, 17 de janeiro de 2020. Disponível em: https://jovempan.com.br/videos/programas/pra-cima-deles/pracimadeles-entrevista-com-a-ministra-damares-alves-17-01-2020.html. Acesso em fevereiro de 2020.

ALVES Damares. Educação domiciliar permite ensinar a pais mais conteúdo que a escola. Globo, 21 de janeiro de 2019a. Disponível em: https://g1.globo.com/politica/blog/ andreia-sadi/post/2019/01/25/damares-educacao-domiciliar-permite-a-pais-ensinar-mais-conteudo-e-gerenciar-aprendizado.ghtml. Acesso em fevereiro de 2020.

ALVES, Damares. "O Estado é laico mas esta ministra é terrivelmente cristã", diz Damares ao assumir direitos humanos. Globo, 02 de janeiro de 2019b. Disponível em: https:// 
g1.globo.com/politica/noticia/2019/01/02/estado-e-laico-mas-esta-ministra-e-terrivelmente-crista-diz-damares-ao-assumir-direitos-humanos.ghtml?utm_source=facebook\&utm medium=social\&utm_campaign=g1\&utm_content=post. Acesso em: 02 jan. 2019.

ALVES, Damares. Em vídeo, Damares diz que 'nova era' começou: 'meninos vestem azul e meninas vestem rosa'. Globo, 2019c. Disponível em: https://g1.globo.com/ politica/noticia/2019/01/03/em-video-damares-alves-diz-que-nova-era-comecou-no-brasil-meninos-vestem-azul-e-meninas-vestem-rosa.ghtml?utm_source=facebook\&utm_ medium=social\&utm_campaign=g1\&utm_content=post. Acesso em: 03 jan. 2019.

BENEVIDES, Maria Victoria. Direitos humanos: desafios para o século XXI. Em: SILVEIRA, Rosa Maria Godoy.; DIAS, Adelaide Alves; FERREIRA, Lúcia de Fátima Guerra; FEITOSA, Maria Luíza Pereira de Alencar Mayer; ZENAIDE, Maria de Nazaré Tavares. Educação em Direitos Humanos: Fundamentos teórico-metodológicos. João Pessoa: Editora Universitária, 2007, p. 335-350.

BARRERA, Paulo. Don't you mess with my children. Conservative inter-religious cooperation in Peru in the XXI Century. In: International Journal Latin American Religious. Vol. 1. 2017, p. 296-308.

BIROLI, Flávia. A “Ideologia de Gênero” e as ameaças à democracia. Blog daBoitempo, 2015. Disponível em: https://blogdaboitempo.com.br/2015/06/26/a--ideologia-de-generoe-as-ameacas-a-democracia/. Acesso em: 06 dez. 2018.

BUTLER, Judith. Corpos que pesam: sobre os limites discursivos do sexo. Em: LOURO, Guacira Lopes (Org.). O corpo educado. Belo Horizonte: Autêntica Editora, p. 151-172, 2001.

BUTLER, Judith. Problemas de gênero: feminismo e subversão da identidade. Rio de Janeiro: Civilização Brasileira, 2003.

CATROGA, Fernando. Entre deuses e césares: secularização, laicidade e religião civil. 1. ed. Coimbra, Almedina, 2006.

CHAGAS, Tiago. Malafaia confirma apoio a Bolsonaro e pretende fazer campanha: “Vou jogar pesado". Gospel Mais, 26 de março de 2018. Disponível em: https://noticias. gospelmais.com.br/malafaia-apoio-bolsonaro-pesado-redes-sociais-96453.html. Acesso em julho de 2019.

FOLHA DE SÃO PAULO. Leia a íntegra do discurso de Bolsonaro na cerimônia de posse no Congresso, 2019. https://www1.folha.uol.com.br/poder/2019/01/leia-a-integra-do-discurso-de-bolsonaro-na-cerimonia-de-posse-no-congresso.shtml. Acesso em fevereiro de 2020

FRANCO, Clarissa De; MARANHÃO F Eduardo Meinberg de Albuquerque. Um Estado terrivelmente cristão e privatizador: a opressão à educação em direitos humanos no governo Bolsonaro. Revista de Estudos Teológicos. No prelo.

FRANCO, Clarissa De. "A Educação oprimida: perspectivas de privatização e teocratização ameaçam o setor”. Folha online. Opinião. Tendências/Debates. 05/02/2020. 
https://www1.folha.uol.com.br/opiniao/2020/02/a-educacao-oprimida.shtml. Acesso em fevereiro de 2020.

GARBAGNOLI, Sara; PREARO, Massimo. La croisade "anti-genre". Du Vatican aux manifs pour tous. Paris, Textuel, Coll. Petite Encyclopédie Critique, 128 p., 2017.

LANGTON, Rae. Feminism in epistemology: exclusion and objectification. In: FRICKER, Miranda; HORNSBY, Jennifer (Orgs.). The Cambridge Companion to Feminism in Philosophy. Cambridge University Press. 2000, pp. 127-145.

LECAROS, Véronique. El Dios del movimiento Con Mis Hijos No Te Metas en el Peru. In: LOURO, Guacira Lopes. Gênero, sexualidade e educação. São Paulo: Vozes, 1997.

MALTA, Magno. Magno Malta: “Continuo confiando em Bolsonaro, faria tudo de novo". Gazeta Online, 2018. Disponível em: https://www.gazetaonline.com.br/noticias/ politica/2018/12/magno-malta--continuo-confiando-em-bolsonaro-faria-tudo-de-novo-1014159548.html. Acesso em julho de 2019.

MARANHÃO $\mathrm{F}^{\circ}$, Eduardo Meinberg de Albuquerque (Org.). Política, Religião e Diversidades: Educação e Espaço Público (Vol. 1). Florianópolis: ABHR / Fogo, 2018, p. 247-259. MARANHÃO $F^{\circ}$, Eduardo Meinberg de Albuquerque. "A travesti morreu, mas carrego ela no caixão" e outras histórias vivas: conversão, transfobia religiosa e morte. Revista Brasileira de História das Religiões, v. 10, n. 9, p. 165-216, 2017.

. “É prá baixar o porrete!" Notas iniciais sobre discursos punitivos discriminatórios acerca das homossexualidades e transgeneridades. Mandrágora, São Bernardo do Campo, v. 21, n. 21, p. 47-87, 2015.

; COELHO, Fernanda Marina Feitosa; DIAS, Tainah Biela. "Fake news acima de tudo, fake news acima de todos": Bolsonaro e o "kit gay", "ideologia de gênero" e fim da "família tradicional”. Correlatio, v. 17, n. 2, p. 65-90, 2018.

. "Matando uma leoa por dia": ideologia de gênero e de gênesis na

"cura” de travestis. Correlatio, v.17, n.2, p.107-148, $2018 a$.

; FRANCO, Clarissa De. "Menino veste azul e menina, rosa” na Educação Domiciliar de Damares Alves: As ideologias de gênero e de gênesis da "ministra terrivelmente cristã" dos Direitos Humanos. Revista Brasileira de História das Religiões, Ano XII, n. 34, 2019.

. "Um tapa na cara pra quem diz que cura gay não existe": A ideologia de gênesis em Cleycianne, Lady Gaga e Marco Feliciano. Religare, v.15, n.2, p. 612-651, $2018 b$.

MARIANO, Ricardo. Laicidade à brasileira. Católicos, pentecostais e evangélicos em disputa na esfera pública. Revista Civitas, vol. 11 , no. 2,. p. 238-258, maio-agosto 2011. MEZZOMO, Frank Antonio. Deputados evangélicos e o Programa Escola Sem Partido na Assembleia Legislativa do Estado do Paraná. In: MARANHÃO Fo, Eduardo Meinberg 
de Albuquerque (Org.). Política, Religião e Diversidades: Educação e Espaço Público (Vol. 1). Florianópolis: ABHR / Fogo, 2018, p. 378-394.

NUGENT, Guillermo. "El Orden Tutelar. Para entender el conflicto entre sexualidad y políticas públicas en América Latina”. En: NUGENT, Guillermo. La trampa de la moral única: argumentos para una democracia laica. Lima: Fundación Ford, 2005.

O ESTADO DE SÃO PAULO. Infográficos: onde estão os representantes das Forças Armadas, 2020. Disponível em: https://www.estadao.com.br/infograficos/politica,mapa-dos-militares-onde-estao-os-representantes-das-forcas-armadas-no-governo-bolsonaro,975096. Acesso em abril de 2020.

PY, Fabio. Cristofascismo à brasileira. Liberdade de expressão e senso crítico, Ativismo protestante. 2018. Disponível em: https://ativismoprotestante.wordpress.com/2018/06/12/ opiniaocristofascimoabrasileira/. Acesso em abril de 2020.

ROSADO-NUNES, Maria José Fontelas. A “ideologia de gênero” na discussão do PNE: a intervenção da hierarquia católica. Horizonte, Belo Horizonte, v. 13, n. 39, p. 1237$1260,2015$.

ROSADO-NUNES, Maria José. Gênero e religião. Rev. Estud. Fem. [conectados], vol.13, n.2 [citado em 2018-11-23], 2005, pp.363-365.

SILVA, Maria Abádia da. O Consenso de Washington e a privatização na educação brasileira. Linhas Críticas, vol. 11, núm. 21, julio-diciembre, 2005, pp. 255-264, p. 260.

WEINTRAUB, Abraham. Governo prevê 216 escolas militares até 2023 e Bolsonaro diz que modelo tem que ser imposto. Folha, setembro de 2019a. Disponível em: https:// www1.folha.uol.com.br/educacao/2019/og/governo-preve-216-escolas-militares-ate-2023-e-bolsonaro-diz-que-modelo-tem-de-ser-imposto.shtml. Acesso em abril de 2020.

WEINTRAUB, Abraham. "Na Biologia é macho ou fêmea, não existe isso de LGBTQI”, diz ministro da Educação em Manaus. Acritica, 2019b. Disponível em https://www.acritica. com/channels/manaus/news/na-biologia-e-macho-ou-femea-nao-existe-lgbtqi-diz-ministro-da-educacao-em-manaus, 2019. Acesso em fevereiro de 2020.

WEINTRAUB, Abraham. Universidades com balbúrdia terão verbas reduzidas, diz Weintraub. Veja, 2019c. Disponível em: https://veja.abril.com.br/brasil/universidades-com-balburdia-terao-verbas-reduzidas-diz-weintraub/. Acesso em janeiro de 2020.

\section{Internet:}

Matéria sobre Ranking de universidades. Disponível em: https://www.nsctotal.com. $\mathrm{br} /$ noticias/mec-cortara-verba-de-universidades-por-balburdia-diz-ministro (acesso em fevereiro de 2020)

Matéria sobre cortes de verbas nas universidades. https://g1.globo.com/educacao/ noticia/2019/05/15/entenda-o-corte-de-verba-das-universidades-federais-e-saiba-como- 
-sao-os-orcamentos-das-10-maiores.ghtml. Acesso em janeiro de 2020. www.escolasempartido.org. Acesso em novembro de 2018.

wWw.programaescolasempartido.org. Acesso em novembro de 2018.

Submetido em: 14-4-2020

Aceito em: 3-6-2020 